Article

\title{
Push-Pull Heterocyclic Dyes Based on Pyrrole and Thiophene: Synthesis and Evaluation of Their Optical, Redox and Photovoltaic Properties
}

\author{
Sara S. M. Fernandes ${ }^{1}$, Maria Cidália R. Castro ${ }^{1}$, Dzmitry Ivanou ${ }^{2}$, Adélio Mendes ${ }^{2} \mathbb{D}$ \\ and Maria Manuela M. Raposo 1,*(D) \\ 1 Centro de Química, Universidade do Minho, Campus de Gualtar, 4710-057 Braga, Portugal; \\ sarasmfernandes@gmail.com (S.S.M.F.); cidaliacastro@quimica.uminho.pt (M.C.R.C.) \\ 2 LEPABE, Departamento de Engenharia Química, Faculdade de Engenharia, Universidade do Porto, \\ 4200-465 Porto, Portugal; ivanou@fe.up.pt (D.I.); mendes@fe.up.pt (A.M.) \\ * Correspondence: mfox@quimica.uminho.pt; Tel.: +351-253-604381; Fax: +351-253-604382
}

\section{check for}

updates

Citation: Fernandes, S.S.M.; Castro, M.C.R.; Ivanou, D.; Mendes, A.; Raposo, M.M.M. Push-Pull Heterocyclic Dyes Based on Pyrrole and Thiophene: Synthesis and Evaluation of Their Optical, Redox and Photovoltaic Properties. Coatings 2022, 12, 34. https://doi.org/ 10.3390/coatings12010034

Academic Editors: Rodica

Mariana Ion and Alessandro Latini

Received: 29 November 2021

Accepted: 23 December 2021

Published: 28 December 2021

Publisher's Note: MDPI stays neutral with regard to jurisdictional claims in published maps and institutional affiliations.

Copyright: (C) 2021 by the authors. Licensee MDPI, Basel, Switzerland. This article is an open access article distributed under the terms and conditions of the Creative Commons Attribution (CC BY) license (https:// creativecommons.org/licenses/by/ $4.0 /)$.

\begin{abstract}
Three heterocyclic dyes were synthesized having in mind the changes in the photovoltaic, optical and redox properties by functionalization of 5-aryl-thieno[3,2-b]thiophene, 5-arylthiophene and bis-methylpyrrolylthiophene $\pi$-bridges with different donor, acceptor/anchoring groups. Knoevenagel condensation of the aldehyde precursors with 2-cyanoacetic acid was used to prepare the donor-acceptor functionalized heterocyclic molecules. These organic metal-free dyes are constituted by thieno[3,2-b]thiophene, arylthiophene, bis-methylpyrrolylthiophene, spacers and one or two cyanoacetic acid acceptor groups and different electron donor groups (alkoxyl, and pyrrole electron-rich heterocycle). The evaluation of the redox, optical and photovoltaic properties of these compounds indicate that 5-aryl-thieno[3,2-b]thiophene-based dye functionalized with an ethoxyl electron donor and a cyanoacetic acid electron acceptor group/anchoring moiety displays as sensitizer for DSSCs the best conversion efficiency (2.21\%). It is mainly assigned to the higher molar extinction coefficient, long $\pi$-conjugation of the heterocyclic system, higher oxidation potential and strong electron donating capacity of the ethoxyl group compared to the pirrolyl moiety.
\end{abstract}

Keywords: heterocyclic push-pull dyes; thiophene; pyrrole; dye-sensitized solar cells; auxiliary donor/acceptor heterocycles; synthesis

\section{Introduction}

Solar energy is a stimulating option for a renewable energy source, among others available, owing to its abundance, simplicity and ability for direct conversion into electricity $[1,2]$.

Dye-sensitized solar cells (DSSCs) belong to the third-generation photovoltaic (PV) devices [3], recently achieving a certified photocurrent conversion efficiency (PCE) of $13 \%$ [4]. Although the 1-Sun PCE of DSSCs is lower when compared to other emerging PVs and conventional Si [5], DSSCs are attracting much research interest due to good performance under dim and diffused light, possibility to produce semi-transparent and flexible modules, simple architecture, sustainable components and low manufacturing cost [6-22]; it makes DSSCs very feasible for building-integrated PV glazing [3,6].

Nowadays, with the rapidly increasing number of low-power wireless communication devices, the Internet of Things (IoTs), the development of cordless powering for them has become imperative $[23,24]$. DSSCs are perfectly fitted for indoor use to address this challenge [25,26]: they display one of the highest among other PV technologies PCE under artificial light - a record of 34.5\% of PCE under 1000 lx light was attained recently [4]. DSSCs are safe for residential use as they are free from toxic soluble lead or tin compounds; they can be produced with several true colors and have an attractive appearance for nice 
and harmonic interior integration. DSSCs devices have started entering the market of indoor PVs [26,27].

The development of new metal-free organic dyes for DSSCs takes much research effort, as properly designed and produced organic dye can display several advantages compared to traditional Ru-complexes [28-33], which are high molar extinction coefficients, easy and cheap synthesis and purification processes and variety and facility of structure alterations, which originate vast options for straightforward tuning of the optoelectronic properties.

Usually, the organic dyes applied have a push-pull structure (donor- $\pi$-bridge-acceptor/ anchoring group), which promotes charge separation and transfer from the ground to the excited state, wide-ranging spectral sensitivity, photostability, controlled aggregation and charge recombination, appropriate Highest Occupied Molecular Orbital (HOMO) and Lowest Unoccupied Molecular Orbital (LUMO) electronic energies and an anchoring group for binding to the surface of a semiconductor [7-22,34-36].

Several studies reveal that heterocyclic molecules of the donor-acceptor type are generally easy to synthesize. Additionally, the introduction of heterocycles with variable electronic structure (electron-deficient or rich) and low aromaticity, into the $\pi$-conjugated molecules are used to tune their optoelectronic and photovoltaic properties and improve their thermal and photochemical stability. It is also well known that the position of the heterocyclic nuclei on the $\pi$-spacers is an important factor. Both types of heterocycles, electron-rich, such as thiophene and pyrrole, and electron-deficient, such as azole and azine derivatives, i.e., (benzo)thiazole benzothiadiazole, pyridine, etc., can act simultaneously as $\pi$-bridges and electron donors or acceptors, respectively [37-53].

Consequently, in the previous two decades, a large amount of investigation regarding the structure/properties relationship of push-pull molecules have been reported due their applications in photovoltaic devices [1-27], nonlinear optics [37,54], Organic Light Emitting Diodes (OLEDs) [55], organic field-effect transistors (OFETs) [56], near infrared absorbing (NIR) dyes [57], etc.

Metal-free heterocyclic dyes bearing functionalized thiophene spacers (oligothiophenes, fused thiophenes, etc.) are usually the most efficient reported sensitizers for DSSC due to their excellent conjugation, charge-transfer properties and smaller geometry relaxation energy [1-27,58-61]. On the other hand, the pyrrole heterocycle has more rarely been used as a conjugated spacer in organic dyes [22,46,62-70], possibly due to its instability, even though it possesses a smaller resonance energy, and could be easily functionalized, not only on the 2-position, but also through the substitution reactions on the $\mathrm{N}-\mathrm{H}$ bond. In fact, our recent research [39-44,46] as well as reported results of other investigators revealed that the stability of these push-pull systems could be enhanced and their optical and electrochemical properties could be finely adjusted by inserting a pyrrole heterocycle into a $\pi$-conjugated system and by alkylation or arylation of the nitrogen of the pyrrole heterocycle [63,64,66-69].

Several acceptor/anchoring moieties, such as phosphoric and sulfonic acid, rhodanine3-acetic acid, aldehyde, pyridine, etc., can be used in DSSCs. Nevertheless, the most used is carboxylic acid in the form of cyanoacetic acid, due to its stability, easy synthesis and higher photovoltaic efficiencies. These results can be explained due to the coplanarity of this anchoring group with the $\pi$-bridge as well as the good coupling with titanium dioxide. It was also demonstrated that correctly designed organic dyes functionalized with two anchors are advantageous to light harvesting, electron (or hole) injection and dark current suppression and they are expected to have better temporal stability on the surface of the electrode compared with the corresponding dyes bearing a single anchoring group $[19,22,34-36,48,71]$.

Earlier, we have communicated the synthesis and application of heterocyclic pushpull sensitizers for DSSCs with several combinations of $\pi$-spacers, electron donor and acceptor/anchoring moieties (Figure 1) [46-50]. 


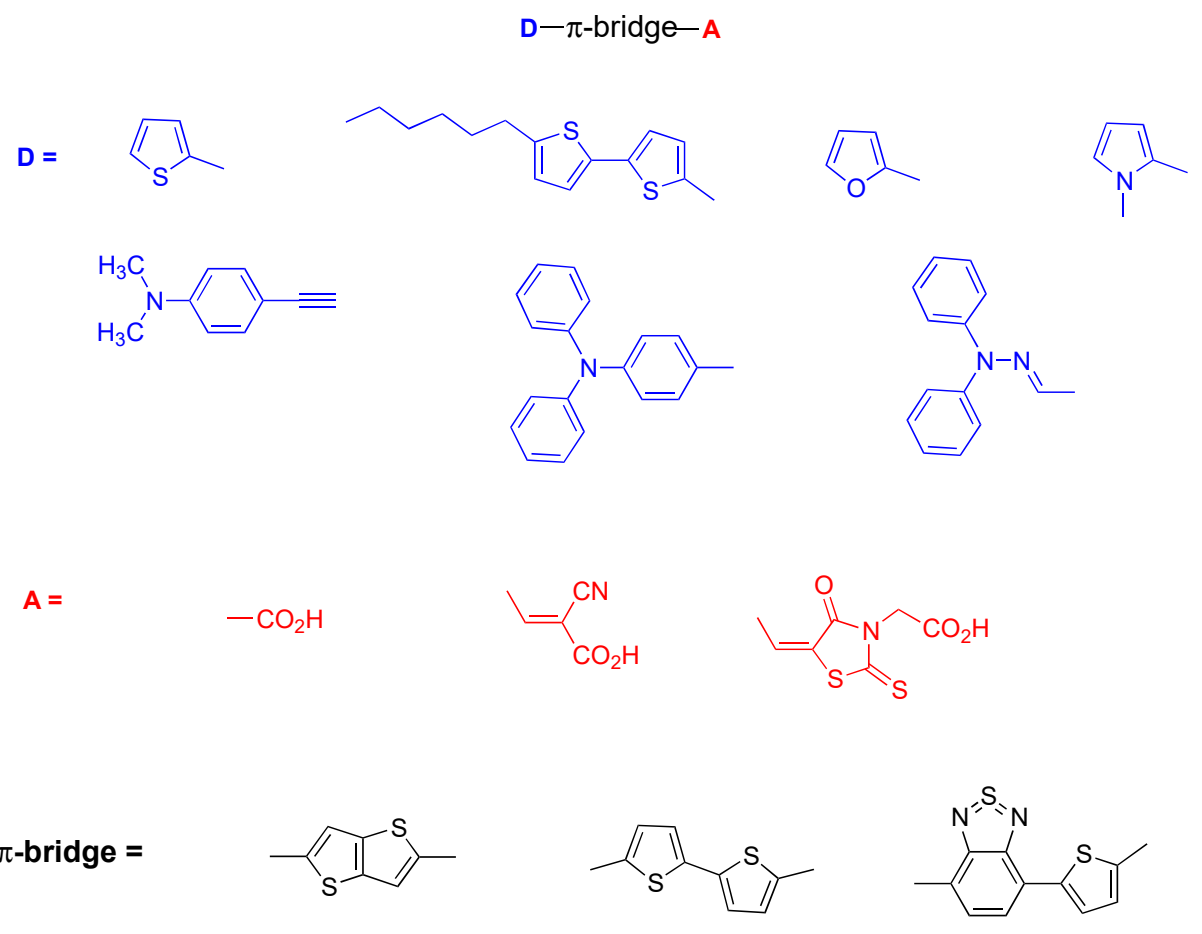

Figure 1. Push-pull heterocyclic sensitizers for DSSCs [46-50].

Taking into account our knowledge on the modification of electrochemical, optical and photovoltaic characteristics of push-pull molecules through the auxiliary electron acceptor or donor effect of heterocycles [39-50], as well as previous studies reported by other groups [7-22,33-36,63-70], we are expanding the research to the preparation of three thiophene and pyrrole-based donor-acceptor heterocyclic molecules. The novel push-pull dyes are constituted by 5-aryl-thieno[3,2-b]thiophene, 5-arythiophene and bismethylpyrrolylthiophene $\pi$-bridges, with one or two cyanoacetic acid anchoring groups, and different electron-donor moieties (ethoxyl and pyrrole electron-rich heterocycle). Optical and electrochemical properties, as well as the efficacy in DSSCs, are assessed.

\section{Materials and Methods}

\subsection{General}

$\mathrm{N}$-Methyl-2-pyrroleboronic acid pinacol ester, 2,5-dibromothiophene and 2-cyanoacetic acid were from Aldrich. All commercially reagents, solvents were used without purification. Precursors 5-(4'-(diethoxy)phenyl] thieno[3,2-b]thiophene-2-carbaldehyde 3 [72] and 5-(4'(1H-pyrrol-1" ${ }^{\prime \prime}$-yl)phenyl)thiophene-2-carbaldehyde 4 [41] were synthesized by us using the experimental procedures described before. Thin-layer chromatography visualization under Ultraviolet-Visible UV light was used to monitor the reaction progress. The purification using silica gel chromatography and the characterization of the dyes, through melting point data, Nuclear Magnetic Resonance (NMR) and UV-visible spectra as well as the study of the redox properties, were obtained as described elsewhere $[46,47,50,73]$.

\subsection{Synthesis}

2.2.1. General Procedure for the Synthesis of Precursor 1 through Suzuki-Miyaura Cross-Coupling

2,5-Dibromothiophene $\left(0.241 \mathrm{~g}, 1.0 \times 10^{-3} \mathrm{~mol}\right)$ was coupled with 1-methyl-1H-pyrrol2-yl)boronic acid pinacol ester $\left(0.580 \mathrm{~g}, 2.4 \times 10^{-3} \mathrm{~mol}\right)$, in a mixture of 1,2-dimethoxyethane (DME) $(8 \mathrm{~mL})$, ethanol $(2 \mathrm{~mL})$, aqueous $2 \mathrm{M} \mathrm{Na}_{2} \mathrm{CO}_{3}(1.7 \mathrm{~mL})$ and $\mathrm{Pd}\left(\mathrm{PPh}_{3}\right)_{4}(0.029 \mathrm{~g}$, $3 \mathrm{~mol} \%)$ at $85{ }^{\circ} \mathrm{C}$ under nitrogen. The reaction time $(24 \mathrm{~h})$ was determinate by thin layer chromatography (TLC). The reaction mixture was extracted, after cooling, with dichloromethane $(3 \times 20 \mathrm{~mL})$, followed by extraction with a saturated solution of $\mathrm{NaCl}$ 
$(20 \mathrm{~mL})$. After the separation of the phases the organic layer was washed with water $(3 \times 10 \mathrm{~mL})$ and with a solution of $\mathrm{NaOH}(10 \%)(10 \mathrm{~mL})$. The organic phase obtained was dried $\left(\mathrm{MgSO}_{4}\right)$ and filtered, and the solvent was removed, giving a crude mixture which was purified using a silica gel chromatography column and mixtures of dichloromethane and light petroleum of increasing polarity affording the pure coupled product 1 [74] .

2,5-bis(N-Methyl-1H-pyrrol-2-yl)thiophene 1. Light green oil (90\%). ${ }^{1} \mathrm{H}$ NMR (DMSO$\left.d_{6}, 400 \mathrm{MHz}\right) \delta 3.74\left(\mathrm{~s}, 6 \mathrm{H}, 2 \times \mathrm{NCH}_{3}\right), 6.04-6.05\left(\mathrm{~m}, 2 \mathrm{H}, 2 \mathrm{x} \mathrm{H}-4^{\prime}\right), 6.24-6.25\left(\mathrm{~m}, 2 \mathrm{H}, 2 \mathrm{x} \mathrm{H}-3^{\prime}\right)$, 6.85-6.86 (m, 2H, 2x H-5'), $7.09(\mathrm{~d}, 2 \mathrm{H}, 3-$ and 4-H, $J=4.0 \mathrm{~Hz}) \mathrm{ppm}$.

\subsubsection{General Procedure for the Synthesis of Aldehyde 2 by Vilsmeier-Haack Formylation}

$\mathrm{POCl}_{3}\left(0.460 \mathrm{~g}, 3.0 \times 10^{-3}\right.$ mol. $)$ was added to DMF $\left(0.219 \mathrm{~g}, 3.0 \times 10^{-3} \mathrm{~mol}\right)$ at $0{ }^{\circ} \mathrm{C}$ and the mixture was stirred for $5 \mathrm{~min}$ at $0{ }^{\circ} \mathrm{C}$. Subsequently, precursor $1(0.242 \mathrm{~g}$, $1.0 \times 10^{-3}$ mol. $)$, dissolved in $\mathrm{DMF}(2 \mathrm{~mL})$, was added dropwise with stirring. The reaction mixture was heated at $60{ }^{\circ} \mathrm{C}$ during $4 \mathrm{~h}$, after which the solution was cooled down to room temperature and then transferred gradually into $10 \mathrm{~mL}$ of saturated sodium acetate aqueous solution and stirred during $30 \mathrm{~min}$. The organic layer obtained was diluted with dichloromethane $(25 \mathrm{~mL})$, washed with saturated $\mathrm{NaHCO}_{3}$ aqueous solution $(2 \times 25 \mathrm{~mL})$ and dried with anhydrous $\mathrm{MgSO}_{4}$. The crude aldehyde 2 was obtained after evaporation of the organic solvent under reduced pressure and its purification was made using a silica gel chromatography column with mixtures of dichloromethane and light petroleum ether with increasing polarity.

5,5'-(Thiophene-2,5-diyl)bis(1-methyl-1H-pyrrole-2-carbaldehyde 2. Yellow solid (50\%). ${ }^{1} \mathrm{H}$ NMR (DMSO- $\left.d_{6}, 400 \mathrm{MHz}\right) \delta 4.05(\mathrm{~s}, 6 \mathrm{H}, 2 \mathrm{xCH}), 6.58$ (d, 2H, 2x H-4, J = 4.4 Hz), $7.10(\mathrm{~d}, 2 \mathrm{H}, 2 \mathrm{x} \mathrm{H}-3, \mathrm{~J}=4.0 \mathrm{~Hz}), 7.52$ (s, 2H, H-3', H-4'), 10.9 (s, 2H, 2x CHO). MS (ESI) $m / z(\%)=299\left([\mathrm{M}+\mathrm{H}]^{+}, 100\right)$. HMRS: $m / z(\mathrm{ESI})$ found $[\mathrm{M}+\mathrm{H}]^{+} 299.0860 ; \mathrm{C}_{16} \mathrm{H}_{15} \mathrm{~N}_{2} \mathrm{O}_{4} \mathrm{~S}$ requires 299.0854 .

2.2.3. General Procedure for the Synthesis of Dyes 5-7 by Knoevenagel Condensation of Aldehydes 2-4 with 2-Cyanoacetic Acid

Four drops of piperidine were added to ethanol solution of the aldehydes $2-4\left(0.2 \times 10^{-3} \mathrm{~mol}\right)$ and 2-cyanoacetic acid $\left(0.022 \mathrm{~g}, 0.26 \times 10^{-3} \mathrm{~mol}\right)$. The solution was stirred at reflux during $6 \mathrm{~h}$. After this time the cooled mixture was evaporated to dryness. Recrystallization from diethyl ether gave the pure products. A similar experimental procedure was used for the synthesis of dye 7 , but in this case, $0.65 \times 10^{-3}$ mol of 2-cyanoacetic acid was used.

2-Cyano-3-(5'-(4"'-ethoxyphenyl)thieno[3,2-b]thiophen-2'-yl)acetic acid 5. Orange solid (26\%). Mp: $199-200{ }^{\circ} \mathrm{C} \lambda_{\max }$ (Ethanol)/nm $399\left(\varepsilon, \mathrm{M}^{-1} \mathrm{~cm}^{-1} 31,370\right) .{ }^{1} \mathrm{H}$ NMR (DMSO- $d_{6}$, $400 \mathrm{MHz}) \delta 1.32\left(\mathrm{t}, 3 \mathrm{H}, \mathrm{CH}_{3}, J=6.9 \mathrm{~Hz}\right), 4.04\left(\mathrm{q}, 2 \mathrm{H}, \mathrm{CH}_{2}, J=6.9 \mathrm{~Hz}\right), 7.00\left(\mathrm{~d}, 2 \mathrm{H}, \mathrm{H}-3^{\prime \prime}, \mathrm{H}-5^{\prime \prime}\right.$, $J=8.8 \mathrm{~Hz}), 7.63\left(\mathrm{~d}, 2 \mathrm{H}, \mathrm{H}-2^{\prime \prime}, \mathrm{H}-6^{\prime \prime}, J=8.8 \mathrm{~Hz}\right), 7.82\left(\mathrm{~s}, 1 \mathrm{H}, \mathrm{H}-3^{\prime}\right), 7.98\left(\mathrm{~s}, 1 \mathrm{H}, \mathrm{H}-6^{\prime}\right), 8.11$ (s, $1 \mathrm{H}, \mathrm{H}-3)$ ppm. Infrared (IR) (Nujol): $v 2206(\mathrm{C} \equiv \mathrm{N}), 1615(\mathrm{C}=\mathrm{O}) \mathrm{cm}^{-1}$. Mass Spectrometry (MS) $(\mathrm{ESI}) \mathrm{m} / z(\%)=358\left([\mathrm{M}+\mathrm{H}]^{+}, 100\right)$. High Resolution Mass Spectra (HMRS): $m / z(\mathrm{ESI})$ found $[\mathrm{M}+\mathrm{H}]^{+} 358.0580 ; \mathrm{C}_{18} \mathrm{H}_{16} \mathrm{NO}_{3} \mathrm{~S}_{2}$ requires 358.0571 .

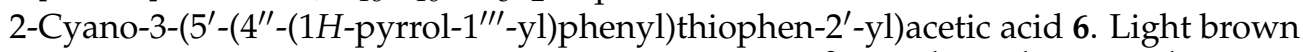
solid (32\%). Mp: $223-225^{\circ} \mathrm{C}$. $\lambda_{\max }\left(\right.$ ethanol) $/ \mathrm{nm} 379\left(\varepsilon / \mathrm{dm}^{3} \mathrm{~mol}^{-1} \mathrm{~cm}^{-1} 26,858\right) .{ }^{1} \mathrm{H}$ NMR $\left(\mathrm{DMSO}^{-} d_{6}, 400 \mathrm{MHz}\right) \delta 6.28\left(2 \mathrm{H}, \mathrm{t}_{\mathrm{ap}}, \mathrm{H}-3^{\prime \prime \prime}, \mathrm{H}-4^{\prime \prime \prime}, J=4.4 \mathrm{~Hz}\right), 7.43\left(2 \mathrm{H}, \mathrm{t}_{\mathrm{ap}}, \mathrm{H}-2^{\prime \prime \prime}, \mathrm{H}-5^{\prime \prime \prime}\right.$, $J=4.4 \mathrm{~Hz}), 7.63-7.78\left(6 \mathrm{H}, \mathrm{m}, \mathrm{H}-3^{\prime}, \mathrm{H}-4^{\prime}, \mathrm{H}-2^{\prime \prime}, \mathrm{H}-3^{\prime \prime}, \mathrm{H}-5^{\prime \prime}, \mathrm{H}-6^{\prime \prime}\right), 8.07$ (1H, s, H-3) ppm. ${ }^{13} \mathrm{C}$ NMR (DMSO- $\left.d_{6}, 400 \mathrm{MHz}\right) \delta 98.2,111,1,(2 \mathrm{C}), 116,5,118,9$ (2 C), 119,7 (2C), 125.0, $127.6,129.0,134.4,140.5,141.5,146.6,152.0,163.6 \mathrm{ppm}$. MS (ESI) $m / z(\%)=321\left([\mathrm{M}+\mathrm{H}]^{+}\right.$, 13), 259 (16), 127 (14), 86 (100). HMRS: $m / z$ (ESI) found $[\mathrm{M}+\mathrm{H}]^{+} 321.0687 ; \mathrm{C}_{18} \mathrm{H}_{13} \mathrm{~N}_{2} \mathrm{O}_{2} \mathrm{~S}$ requires $[\mathrm{M}+\mathrm{H}]^{+} 321.0692$.

3,3-(Thiophene-2" ${ }^{\prime \prime}, 5^{\prime \prime}$-diylbis (1'-methyl-1H-pyrrole-5', $2^{\prime}$-diyl))bis(2-cyanoacetic acid) 7. Black solid (48\%). Mp: 207-209 ${ }^{\circ} \mathrm{C}$. $\lambda_{\max }$ (DMSO)/nm $432\left(\varepsilon / \mathrm{dm}^{3} \mathrm{~mol}^{-1} \mathrm{~cm}^{-1} 17,517\right) .{ }^{1} \mathrm{H}$ NMR (DMSO- $\left.d_{6}, 400 \mathrm{MHz}\right) \delta 3.83\left(6 \mathrm{H}, \mathrm{s}, 2 \times \mathrm{CH}_{3}\right), 6.65\left(2 \mathrm{H}, \mathrm{s}, 2 x \mathrm{H}-4^{\prime}\right), 7.38\left(2 \mathrm{H}, \mathrm{d}, \mathrm{H}-3^{\prime}\right.$, $J=4.0 \mathrm{~Hz}), 7.42\left(2 \mathrm{H}, \mathrm{s}, \mathrm{H}-4^{\prime \prime}, \mathrm{H}-5^{\prime \prime}\right), 8.00(2 \mathrm{H}, \mathrm{s}, \mathrm{H}-3) \mathrm{ppm}$. MS (ESI) $m / z(\%)=433\left([\mathrm{M}+\mathrm{H}]^{+}\right.$, 100), 102 (2). HMRS: $m / z$ (ESI) found $[\mathrm{M}+\mathrm{H}]^{+} 433.0965 ; \mathrm{C}_{22} \mathrm{H}_{17} \mathrm{~N}_{4} \mathrm{O}_{4} \mathrm{~S}$ requires 433.0970 . 


\subsection{Preparation and Characterization of DSSCS}

The efficacy of new dyes as photosensitizers in DSSCs was assessed. DSSCs were assembled and characterized using procedures described in [50]. Five cells were prepared for each dye and the average parameters are presented.

\section{Results and Discussion}

\subsection{Design, Synthesis and Characterization of Dyes 5-7 and for the Aldehyde Precursor 2}

Three novel donor-acceptor heterocyclic dyes 5-7 bearing diverse $\pi$-spacers constituted by aryl, thiophene and pyrrole nuclei, and different donor groups were produced, keeping in mind the evaluation of their redox, optical and photovoltaic behavior. It is well known that the synthesis and the study of the structure-photovoltaic performance relationship of new metal free organic dyes in DSSCs is of great importance for understanding the prospects of this dyes for application in DSSCs. Moreover, the synthesis and evaluation of novel heterocyclic dyes in which the pyrrole heterocycle is functionalized in positions 1 or 2 performing simultaneously the role of auxiliary electron donor group and $\pi$-spacer, are of great interest in order to disclose the best design for application as sensitizers for DSSCs. Therefore, 5-aryl-thieno[3,2-b] thiophene 5, pyrrolylphenylthiophene 6 and bis-methylpyrrolylthiophene 7 derivatives, were synthesized and purified through simple synthetic and isolation procedures (Schemes 1 and 2).

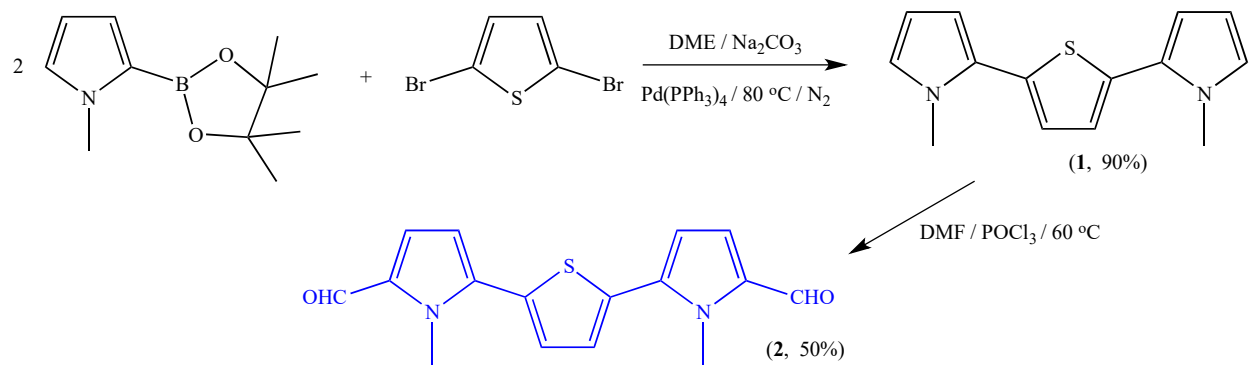

Scheme 1. Pyrrole precursors (1-2) synthesis by Suzuki-Miyaura coupling and Vilsmeier formylation, respectively.

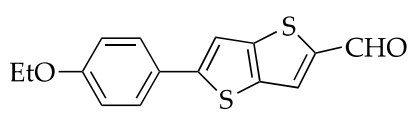

3<smiles>O=Cc1ccc(-c2ccc(-n3cccc3)cc2)s1</smiles>

4<smiles>Cn1c(C=O)ccc1-c1ccc(-c2ccc(C=O)n2C)s1</smiles>

(i)<smiles>CCOc1ccc(-c2cc3sc(/C=C(\C#N)C(=O)O)cc3s2)cc1</smiles>

(5, 26\%)<smiles>N#C/C(=C\c1ccc(-c2ccc(-n3cccc3)cc2)s1)C(=O)O</smiles>

(6, 32\%)<smiles>Cn1c(/C=C(\C#N)C(=O)O)ccc1/C=C(\C#N)C(=O)O</smiles>

(7, 48\%)

Scheme 2. Synthesis of dyes 5-7: (i) 2-cyanoacetic acid (1.3 equiv.)/ethanol/piperidine/reflux; (ii) 2-cyanoacetic acid (2.5 equiv.)/ethanol/piperidine/reflux.

The aldehyde precursors 2-4 were prepared using several synthetic methodologies developed by our research group. Therefore, aldehyde 2 was synthesized in 50\% yield, by Vilsmeier formylation of the precursor 2,5-bis( $N$-methyl-1H-pyrrol-2-yl)thiophene 1 [74], which in turn was prepared by Suzuki-Myiaura coupling, in $90 \%$ yield, of 2,5- 
dibromothiophene with 1-methyl-1H-pyrrol-2-yl) boronic acid, both commercially available (Scheme 1).

On the other hand, compounds 3 [72] and 4 [41] were prepared directly through Suzuki-Miyaura cross coupling, as described recently by our group of investigation.

Knoevenagel condensation was used for the synthesis of donor-acceptor heterocyclic dyes 5-7 (Scheme 2). Therefore, aldehyde precursors 2-4 and 2-cyanoacetic acid were refluxed for $6 \mathrm{~h}$ in ethanol with the addition of four drops of piperidine as a catalyst.

Standard spectroscopic techniques were used to characterize the metal-free organic dyes 5-7 (Table 1). ${ }^{1} \mathrm{H}$ NMR spectra for all compounds showed the characteristic singlet of the vinylic- $H$, which indicates the presence of the ethylenic spacer in these molecules.

Table 1. Reaction yields and data from UV-Vis spectra and ${ }^{1} \mathrm{H}$ NMR for push-pull heterocyclic dyes 5-7.

\begin{tabular}{|c|c|c|c|c|}
\hline \multirow{2}{*}{ Dye } & \multirow{2}{*}{ Yield (\%) } & \multicolumn{2}{|c|}{ UV-Vis ${ }^{1}$} & \multirow{2}{*}{$\begin{array}{c}{ }^{1} \mathrm{H} \mathrm{NMR}^{2} \\
H_{\text {vinylic }}(\mathrm{ppm}) \\
\end{array}$} \\
\hline & & $\lambda_{\max }(\mathrm{nm})$ & $\varepsilon\left(\mathbf{M}^{-1} \mathrm{~cm}^{-1}\right)$ & \\
\hline 5 & 20 & 399 & 31,370 & 8.11 \\
\hline 6 & 32 & 379 & 26,858 & 8.07 \\
\hline 7 & 48 & 432 & 17,517 & 8.00 \\
\hline
\end{tabular}

${ }^{1}$ UV-Vis spectra were performed in ethanol for all compounds, except for compound 7, where DMSO was used ${ }^{2}$ For all compounds, NMR spectra were recorded in DMSO- $d_{6}$.

Absorption spectra in the UV-Vis range for the four push-pull heterocyclic dyes synthesized was recorded, at room temperature, in an ethanol solution for dyes $\mathbf{5}$ and $\mathbf{6}$, and in a DMSO solution for dye 7 due to solubility issues in other solvents (Figure 2). All compounds exhibit a strong and broad absorption band, with the maximum absorption dependent on the electronic properties of the donor group, strength for electron withdraw of the anchoring group and overall $\pi$-conjugation of the molecule. Dye 6 exhibited the shorter wavelength of $379 \mathrm{~nm}$, which might be attributed to the presence of the pyrrole heterocycle as the donor moiety; this is because the nitrogen electron pair is not available for delocalization in the push-pull system due to its involvement in the aromatic system, resulting in a higher electronic band gap $[41,46,69,75]$. Additionally, this dye has a small conjugation due to its $\pi$-spacer constituted by an arylthiophene unit [52]. Dye 7 showed an absorption band centered at $432 \mathrm{~nm}$. An additional absorption band in the long wavelengths manifests itself with an absorption peak at $698 \mathrm{~nm}$. The band with a peak at $432 \mathrm{~nm}$ is originated from $\pi-\pi^{*}$ transition in the conjugated system; the band centered at $698 \mathrm{~nm}$ could be assigned to the absorption by 2,5-bis( $N$-methyl-1H-pyrrol-2-yl)thiophene moiety.

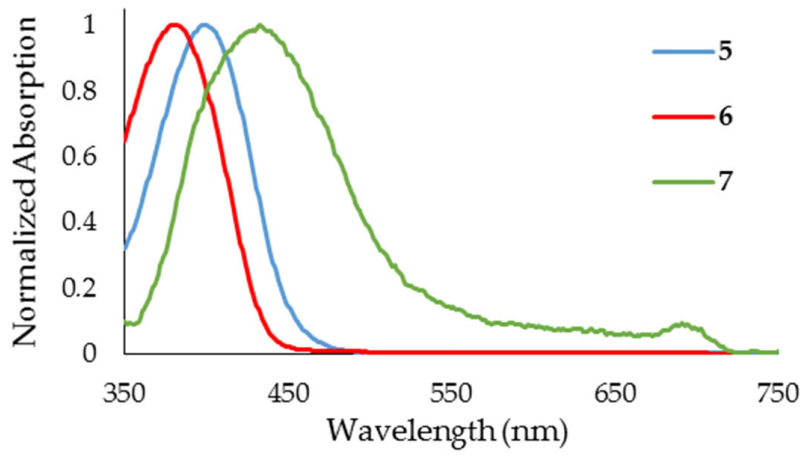

Figure 2. Absorption spectra of push-pull heterocyclic dyes $\mathbf{5}$ and $\mathbf{6}$ in ethanol and dye $\mathbf{7}$ in DMSO, at room temperature.

\subsection{Electrochemical Study}

The energy levels of the LUMO and HOMO of the dye play an important role for sensitization of DSSCs. For electron injection from the $\mathrm{LUMO}$ of a dye into $\mathrm{TiO}_{2}$ its energy 
level should be higher than the conduction band edge of semiconductor. Oxidized form of the dye is regenerated only when the energy level of $\mathrm{HOMO}$ is below equilibrium potential of the redox couple used. Cyclic voltammetry provided information on the oxidation and reduction potentials for dyes 5-7, HOMO and LUMO energies [76] and their band gaps calculated as $\mathrm{E}_{\mathrm{LUMO}}-\mathrm{E}_{\mathrm{HOMO}}$ [77] (Table 2).

Table 2. Reduction and oxidation potentials; HOMO and LUMO energies and band gaps for dyes 5-7.

\begin{tabular}{cccccc}
\hline Dye & $\begin{array}{c}\text { Reduction } \\
\mathbf{( V )}\end{array}$ & $\begin{array}{c}\text { Oxidation }^{\mathbf{1}} \\
\mathbf{( V )}\end{array}$ & $\begin{array}{c}\mathbf{E}_{\text {HOMO }}{ }^{\mathbf{2}} \\
\mathbf{( e V )}\end{array}$ & $\begin{array}{c}\text { E }_{\text {LUMO }}{ }^{2} \\
(\mathbf{e V})\end{array}$ & $\begin{array}{c}\text { Band Gap }^{\mathbf{3}} \\
(\mathbf{e V})\end{array}$ \\
\hline $\mathbf{5}$ & -1.65 & 0.83 & -5.22 & -2.74 & 2.48 \\
$\mathbf{6}$ & -1.96 & 0.53 & -4.92 & -2.43 & 2.49 \\
$\mathbf{7}$ & -1.91 & 0.25 & -4.64 & -2.48 & 2.16 \\
\hline
\end{tabular}

${ }^{1}$ Measured in $1.0 \mathrm{mM}$ solution of the dye in dry DMF with the addition of $0.1 \mathrm{M}$ of $\left[\mathrm{NBu}_{4}\right]\left[\mathrm{BF}_{4}\right]$. Scan rate of potential $0.1 \mathrm{~V} \mathrm{~s}^{-1}$. Potentials $(\mathrm{E})$ are given vs. $\mathrm{Fc}^{+} / \mathrm{Fc}$ redox coupl. ${ }^{2} \mathrm{E}_{\mathrm{LUMO}}=-\left(\mathrm{E}_{\mathrm{red}}+4.39\right)(\mathrm{eV})$ and $\mathrm{E}_{\mathrm{LUMO}}=-\left(4.39+\mathrm{E}_{\mathrm{OX}}\right)(\mathrm{eV})[46,73,76] \cdot{ }^{3}$ Calculated as $\mathrm{E}_{\mathrm{LUMO}}-\mathrm{E}_{\mathrm{HOMO}}[77]$.

The reduction potential for all dyes $5-7$ is at $-1.65,-1.96$ and $-1.91 \mathrm{~V}$, respectively (for details, please see the Figures S1-S3), which is less than the $\mathrm{TiO}_{2}$ conduction band energy $(-0.50 \mathrm{~V})$, meaning that the injection of electrons from $\mathrm{LUMO}$ of the dye into $\mathrm{TiO}_{2}$ is permitted energetically [78]. The equilibrium potential of $\mathrm{I}_{3}{ }^{-} / 3 \mathrm{I}^{-}$redox pair is $0.42 \mathrm{~V}$, which indicates that dyes 5 and 6, with oxidation potentials of 0.83 and $0.53 \mathrm{~V}$, respectively, will accept electrons from $\mathrm{I}^{-}$, and thus, return to their initial state. Dye 5 has higher oxidation potential than dye 6 and it is regenerated easier. The oxidation potential of dye 7 $(0.25 \mathrm{~V})$ is much lower than that of the $\mathrm{I}_{3}{ }^{-} / 3 \mathrm{I}^{-}$redox pair. Therefore, dye regeneration is thermodynamically unfavorable.

\subsection{Evaluation of DSSCs Performance}

Figure 3 a presents photocurrent-voltage $(I-V)$ curves of the DSSCs employing as sensitizers the dyes 5-7. All the DSSCs show typical photodiode behavior. From $I-V$ curves, the key parameters of photovoltaic performance (efficiency, $\eta$; fill factor, FF; shortcircuit current density, $J_{S C}$ and open circuit voltage, $V_{O C}$ ) of the DSSCs were calculated and presented in Table 3.

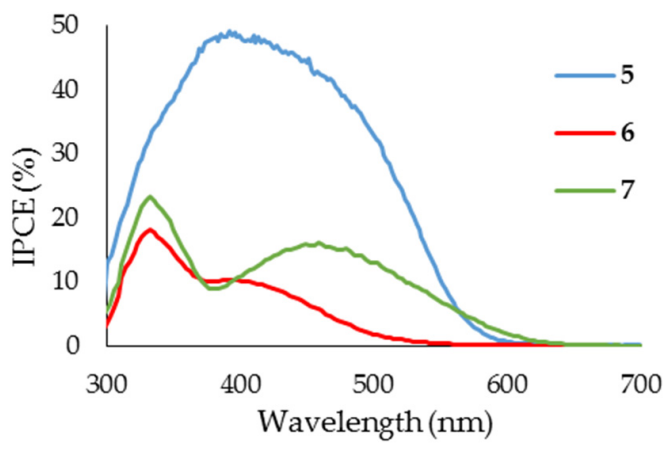

(a)

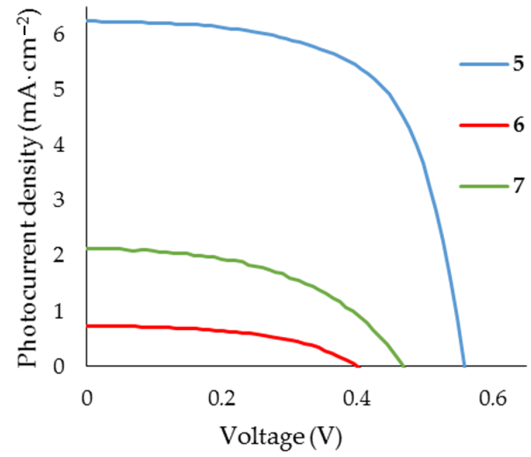

(b)

Figure 3. $I-V$ curves (a) and IPCE (b) of the DSSCs prepared using dyes 5-7.

Table 3. Photovoltaic parameters of DSSCs sensitized with molecules 5-7.

\begin{tabular}{ccccc}
\hline Dye & $V_{\text {OC }}(\mathbf{V})$ & $J_{\text {SC }}\left(\mathbf{m A} \cdot \mathbf{c m}^{-2}\right)$ & $F F(\%)$ & $\eta(\%)$ \\
\hline $\mathbf{5}$ & 0.56 & 6.24 & 0.63 & 2.21 \\
$\mathbf{6}$ & 0.37 & 0.64 & 0.50 & 0.13 \\
$\mathbf{7}$ & 0.44 & 1.74 & 0.49 & 0.40
\end{tabular}


The lowest efficiency of DSSCs was observed for the cell sensitized with dye 6 $(0.13 \%)$. The lowest values of open circuit voltage $(0.37 \mathrm{~V})$ and short-circuit current density $\left(0.64 \mathrm{~mA} \cdot \mathrm{cm}^{-2}\right)$ were also observed for the DSSC sensitized with dye 6 . This is in accordance with data obtained by cyclic voltammetry-the regeneration of the dye to its fundamental state being inefficient will hinder the injection of electrons into the semiconductor. Quantum yield of the photocurrent in the DSSC sensitized with dye 6 is less than $10 \%$ in spectral region above $370 \mathrm{~nm}$ (Figure $3 \mathrm{~b}$ ), confirming the low ability of photoexcited dye to inject electrons into $\mathrm{TiO}_{2}$.

Dye 7 exhibited an intermediate performance as a sensitizer with a DSSC photovoltaic efficiency of $0.40 \%$. The best efficiency of this series of DSSCs, $2.21 \%$, was achieved using dye 5. The IPCE response of this cells is significantly higher and broads up to $580 \mathrm{~nm}$. Such a feature is attributed to the strong anchoring and electron withdrawing ability of the 2-cyanoacetic acid, long $\pi$-conjugation of the heterocyclic system and the high molar extinction coefficient of the dye $\left(31,370 \mathrm{M}^{-1} \mathrm{~cm}^{-1}\right)$.

\section{Conclusions}

Three donor-acceptor heterocyclic dyes 5-7 bearing diverse $\pi$-spacers (aryl, thiophene, pyrrole), and different number of anchoring groups, were prepared having in mind the evaluation of the redox and optical properties as well as the photovoltaic performance in DSSCs. All heterocyclic dyes were synthesized by a combination of several methodologies, such as Suzuki-Miyaura cross coupling, Vilsmeier formylation, and Knoevenagel condensation, and characterized using standard spectroscopic techniques.

The absorption spectroscopy study of all compounds exhibited strong and broad bands of absorption, with the wavelength of maximum absorption dependent on the ability for donation of electrons of the donor group, the strength of the acceptor/anchoring group to withdraw electrons, and on the overall $\pi$-conjugation of the dye.

The prepared dyes were used as sensitizers in nanocrystalline $\mathrm{TiO}_{2}$ DSSCs, revealing photovoltaic conversion efficiencies in the range of $0.13 \%-2.21 \%$. Dye 5 , based on aryl-thieno[3,2-b]thiophene spacer, functionalized with an ethoxyl donor group and a cyanoacetic acid anchoring moiety/electron acceptor group, exhibited the highest overall conversion efficiency (2.21\%) as sensitizer, which is ascribed to long $\pi$-conjugation of the heterocyclic system, higher oxidation potential, higher molar extinction coefficient and strong withdrawing of electrons and anchoring ability of the cyanoacetic acid. Electrochemical study of dyes 5-7 by cyclic voltammetry revealed that for dye 7 , the oxidation potential is lower than that of the redox couple $\mathrm{I}^{-} / \mathrm{I}_{3}{ }^{-}$, indicating an inefficient regeneration of this dye from its oxidized state.

Supplementary Materials: The following supporting information can be downloaded at: https: / / www.mdpi.com/article/10.3390/coatings12010034/s1. Figure S1. Cyclic voltammetry plots of compound 2-cyano-3-(5'-(4'-ethoxyphenyl)thieno[3,2-b]thiophen-2'-yl)acetic acid (5), in dry DMF $\left(\mathrm{C}=10^{-4} \mathrm{M}\right)$; Figure S2. Cyclic voltammetry plots of compound 2-cyano-3-(5'-(4'-(1H-pyrrol- $1^{\prime \prime \prime}-$ yl)phenyl)thiophen-2'-yl)acetic acid (6), in dry DMF $\left(C=10^{-4} \mathrm{M}\right)$; Figure S3. Cyclic voltammetry plots of compound 3,3-(thiophene- $2^{\prime \prime}, 5^{\prime \prime}$-diyl-bis ( $1^{\prime}$-methyl-1H-pyrrole-5' $5^{\prime} 2^{\prime}$-diyl))-bis(2-cyanoacetic acid) (7), in dry DMF $\left(\mathrm{C}=10^{-4} \mathrm{M}\right)$. All the experiments were performed using glassy carbon as working electrode, a platinum wire as counter electrode, and acetonitrile $\mathrm{Ag} / \mathrm{Ag}^{+}$electrode as reference. [NBu4][BF4] $(0.1 \mathrm{M})$ was used as supporting electrolyte and the collected data were referenced to the potential of $\mathrm{Fc} / \mathrm{FC}^{+}$couple.

Author Contributions: Conceptualization, M.M.M.R.; Funding acquisition, M.M.M.R. and A.M.; Investigation, S.S.M.F., M.C.R.C. and D.I.; Methodology, M.M.M.R.; Supervision, M.M.M.R. and A.M.; Writing—original draft, M.M.M.R. and S.S.M.F.; Writing-review and editing, M.M.M.R. and D.I. All authors have read and agreed to the published version of the manuscript.

Funding: Thanks are due to the Fundação para a Ciência e Tecnologia (FCT) for a PhD grant to S.S.M. Fernandes (SFRH/BD/87786/2012) and to FEDER-COMPETE for financial support at the research center CQUM (UID/QUI/0686/2016) and (UID/QUI/0686/2020). The NMR spectrometers are 
part of the National NMR Network (PTNMR) and are partially supported by Infrastructure Project No. 022161 (co-financed by FEDER through COMPETE 2020, POCI and PORL and FCT through PIDDAC). The group in Porto would like to acknowledge the European Commission through the Seventh Framework Programme, the Specific Programme "Ideas" of the European Research Council for research and technological development as part of an Advanced Grant under Grant No. 321315, which also partially funded this work. Some of this work was also performed under the project "SunStorage-Harvesting and storage of solar energy", with reference POCI-01-0145-FEDER-016387, funded by the European Regional Development Fund (ERDF), through COMPETE 2020-Operational Programme for Competitiveness and Internationalization (OPCI), and by national funds, through FCT. The group in Porto is also thankful to POCI-01-0145-FEDER-006939 (Laboratory for Process Engineering, Environment, Biotechnology and Energy-UID/EQU/00511/2013) funded by the European Regional Development Fund (ERDF), through COMPETE2020_Programa Operacional Competitividade e Internacionalização (POCI) and by national funds, through FCT-Fundação para a Ciência e a Tecnologia and NORTE-01-0145-FEDER-000005-LEPABE-2-ECO-INNOVATION, supported by the North Portugal Regional Operational Programme (NORTE 2020), under the Portugal 2020 Partnership Agreement, through the European Regional Development Fund (ERD).

Institutional Review Board Statement: Not applicable.

Informed Consent Statement: Not applicable.

Data Availability Statement: Not applicable.

Conflicts of Interest: The authors declare no conflict of interest.

\section{References}

1. Grätzel, M. Conversion of sunlight to electric power by nanocrystalline dye-sensitized solar cells. J. Photochem. Photobiol. A 2004, 164, 3-14. [CrossRef]

2. Gonçalves, L.M.; Bermudez, V.Z.; Ribeiro, H.A.; Mendes, A.M. Dye-sensitized solar cells: A safe bet for the future. Energy Environ. Sci. 2008, 1, 655-667. [CrossRef]

3. Muñoz-García, A.B.; Benesperi, I.; Boschloo, G.; Concepcion, J.J.; Delcamp, J.H.; Gibson, E.A.; Meyer, G.J.; Pavone, M.; Pettersson, H.; Hagfeldt, A.; et al. Dye-sensitized solar cells strike back. Chem. Soc. Rev. 2021, 50, 12450-12550. [CrossRef]

4. Zhang, D.; Stojanovic, M.; Ren, Y.; Cao, Y.; Eickemeyer, F.T.; Socie, E.; Vlachopoulos, N.; Moser, J.E.; Zakeeruddin, S.M.; Hagfeldt, A.; et al. A molecular photosensitizer achieves a Voc of $1.24 \mathrm{~V}$ enabling highly efficient and stable dye-sensitized solar cells with copper(II/I)-based electrolyte. Nat. Commun. 2021, 12, 2-11. [CrossRef] [PubMed]

5. Green, M.A.; Dunlop, E.D.; Hohl-Ebinger, J.; Yoshita, M.; Kopidakis, N.; Hao, X. Solar cell efficiency tables (Version 58). Prog. Photovolt. Res. Appl. 2021, 29, 657-667. [CrossRef]

6. Kokkonen, M.; Talebi, P.; Zhou, J.; Asgari, S.; Soomro, S.A.; Elsehrawy, F.; Halme, J.; Ahmad, S.; Hagfeldt, A.; Hashmi, S.G. Advanced research trends in dye-sensitized solar cells. J. Mater. Chem. A 2021, 9, 10527-10545. [CrossRef] [PubMed]

7. Robertson, N. Optimizing dyes for dye-sensitized solar cells. Angew. Chem. Int. Ed. 2006, 45, 2338-2345. [CrossRef]

8. Mishra, A.; Fischer, M.K.R.; Bäuerle, P. Metal-free organic dyes for dye-sensitized solar cells: From structure: Property relationships to design rules. Angew. Chem. Int. Ed. 2009, 48, 2474-2499. [CrossRef] [PubMed]

9. Ooyama, Y.; Harima, Y. Molecular designs and synthesis of organic dyes for dye-sensitized solar cells. Eur. J. Org. Chem. 2009, 18, 2903-2934. [CrossRef]

10. Hagfeldt, A.; Boschloo, G.; Sun, L.; Kloo, L.; Pettersson, H. Dye-sensitized solar cells. Chem. Rev. 2010, 110, 6595-6663. [CrossRef]

11. Ning, Z.; Fu, Y.; Tian, H. Improvement of dye-sensitized solar cells: What we know and what we need to know. Energy Environ. Sci. 2010, 3, 1170-1181. [CrossRef]

12. Clifford, J.N.; Martinez-Ferrero, E.; Viterisi, A.; Palomares, E. Sensitizer molecular structure-device efficiency relationship in dye sensitized solar cells. Chem. Soc. Rev. 2011, 40, 1635-1646. [CrossRef]

13. Ooyama, Y.; Harima, Y. Photophysical and electrochemical properties, and molecular structures of organic dyes for dye-sensitized solar cells. ChemPhysChem 2012, 13, 4032-4080. [CrossRef]

14. Yen, Y.-S.; Chou, H.-H.; Chen, Y.-C.; Hsu, C.-Y.; Lin, J.T. Recent developments in molecule-based organic materials for dyesensitized solar cells. J. Mater. Chem. 2012, 22, 8734-8747. [CrossRef]

15. Kanaparthi, R.K.; Kandhadi, J.; Giribabu, L. Metal-free organic dyes for dye-sensitized solar cells: Recent advances. Tetrahedron 2012, 68, 8383-8393. [CrossRef]

16. Kim, B.-G.; Chung, K.; Kim, J. Molecular design principle of all-organic dyes for dye-sensitized solar cells. Chem. Eur. J. 2013, 19, 5220-5230. [CrossRef]

17. $\mathrm{Wu}, \mathrm{Y}$.; Zhu, W. Organic sensitizers from D- $\pi$-A to D-A- $\pi-\mathrm{A}$ : Effect of the internal electron-withdrawing units on molecular absorption, energy levels and photovoltaic performances. Chem. Soc. Rev. 2013, 42, 2039-2058. [CrossRef] [PubMed] 
18. Ahmad, S.; Guillen, E.; Kavan, L.; Grätzel, M.; Nazeeruddin, M.K. Metal free sensitizer and catalyst for dye sensitized solar cells. Energy Environ. Sci. 2013, 6, 3439-3466. [CrossRef]

19. Sugathan, V.; John, E.; Sudhakar, K. Recent improvements in dye sensitized solar cells: A review. Renew. Sustain. Energy Rev. 2015, 52, 54-64. [CrossRef]

20. Obotowo, I.N.; Obot, I.B.; Ekpe, U.J. Organic sensitizers for dye-sensitized solar cell (DSSC): Properties from computation, progress and future perspectives. J. Mol. Struct. 2016, 1122, 80-87. [CrossRef]

21. Maçaira, J.; Andrade, L.; Mendes, A. Modeling, simulation and design of dye sensitized solar cells. RSC Adv. 2014, 4, 2830-2844 [CrossRef]

22. Chaurasia, S.; Lin, J.T. Metal-free sensitizers for dye-sensitized solar cells. Chem. Rec. 2016, 16, 1311-1336. [CrossRef] [PubMed]

23. Curry, J.; Harris, N. Powering the environmental internet of things. Sensors 2019, 19, 1940. [CrossRef] [PubMed]

24. Mishu, M.K.; Rokonuzzaman, M.; Pasupuleti, J.; Shakeri, M.; Rahman, K.S.; Hamid, F.A.; Tiong, S.K.; Amin, N. Prospective efficient ambient energy harvesting sources for IoT-equipped sensor applications. Electronics 2020, 9, 1345. [CrossRef]

25. Michaels, H.; Rinderle, M.; Freitag, R.; Benesperi, I.; Edvinsson, T.; Socher, R.; Gagliardi, A.; Freitag, M. Dye-sensitized solar cells under ambient light powering machine learning: Towards autonomous smart sensors for the Internet of things. Chem. Sci. 2020, 11, 2895-2906. [CrossRef] [PubMed]

26. Aslam, A.; Mehmood, U.; Arshad, M.H.; Ishfaq, A.; Zaheer, J.; Ul Haq Khan, A.; Sufyan, M. Dye-sensitized solar cells (DSSCs) as a potential photovoltaic technology for the self-powered internet of things (IoTs) applications. Sol. Energy 2020, 207, 874-892. [CrossRef]

27. Mathews, I.; Kantareddy, S.N.; Buonassisi, T.; Peters, I.M. Technology and market perspective for indoor photovoltaic cells. Joule 2019, 3, 1415-1426. [CrossRef]

28. O'Regan, B.; Grätzel, M. A low-cost, high-efficiency solar cell based on dye-sensitized colloidal $\mathrm{TiO}_{2}$ films. Nature 1991, 353, 737-740. [CrossRef]

29. Grätzel, M. Dye-sensitized solar cells. J. Photochem. Photobiol. C 2003, 4, 145-153. [CrossRef]

30. Grätzel, M. Recent advances in sensitized mesoscopic solar cells. Acc. Chem. Res. 2009, 42, 1788-1798. [CrossRef]

31. Yella, A.; Lee, H.-W.; Tsao, H.N.; Yi, C.; Chandiran, A.K.; Nazeeruddin, M.K.; Diau, E.W.-G.; Yeh, C.-Y.; Zakeeruddin, S.M.; Grätzel, M. Porphyrin-sensitized solar cells with cobalt (II/III)-based redox electrolyte exceed 12\% efficiency. Science 2011, 334, 629-634. [CrossRef]

32. Bignozzi, C.A.; Argazzi, R.; Boaretto, R.; Busatto, E.; Carli, S.; Ronconi, F.; Caramori, S. The role of transition metal complexes in dye sensitized solar devices. Coord. Chem. Rev. 2013, 257, 1472-1492. [CrossRef]

33. Pashaei, B.; Shahroosvand, H.; Grätzel, M.; Nazeeruddin, M.K. Influence of ancillary ligands in dye-sensitized solar cells. Chem. Rev. 2016, 116, 9485-9564. [CrossRef] [PubMed]

34. Zhang, L.; Cole, J.M. Anchoring groups for dye-sensitized solar cells. ACS Appl. Mater. Interfaces 2015, 7, 3427-3455. [CrossRef] [PubMed]

35. Kwon, D.Y.; Chang, D.M.; Kim, Y.S. Effect of electron withdrawing unit for dye-sensitized solar cell based on D-A- $\pi$-A organic dyes. Mater. Res. Bull. 2014, 58, 93-96. [CrossRef]

36. Liu, B.; Li, W.; Wang, B.; Li, X.; Liu, Q.; Naruta, Y.; Zhu, W. Influence of different anchoring groups in indoline dyes for dye-sensitized solar cells: Electron injection, impedance and charge recombination. J. Power Sources 2013, 234, 139-146. [CrossRef]

37. Bureš, F. Fundamental aspects of property tuning in push-pull molecules. RSC Adv. 2014, 4, 58826-58851. [CrossRef]

38. Albert, I.D.L.; Marks, T.J.; Ratner, M.A. Large molecular hyperpolarizabilities: Quantitative analysis of aromaticity and auxiliary donor-acceptor effects. J. Am. Chem. Soc. 1997, 119, 6575-6582. [CrossRef]

39. Raposo, M.M.M.; Sousa, A.M.R.C.; Kirsch, G.; Cardoso, P.; Belsley, M.; de Matos Gomes, E.; Fonseca, A.M.C. Synthesis and characterization of dicyanovinyl-substituted thienylpyrroles as new nonlinear optical chromophores. Org. Lett. 2006, 8, 3681-3684 [CrossRef] [PubMed]

40. Pina, J.; Seixas de Melo, J.S.; Batista, R.M.F.; Costa, S.P.G.; Raposo, M.M.M. The influence of the relative position of the thiophene and pyrrole rings in donor-acceptor thienylpyrrolyl-benzothiazole derivatives. A photophysical and theoretical investigation. Phys. Chem. Chem. Phys. 2010, 12, 9719-9725. [CrossRef]

41. Castro, M.C.R.; Belsley, M.; Fonseca, A.M.C.; Raposo, M.M.M. Synthesis and characterization of novel second-order NLOchromophores bearing pyrrole as an electron donor group. Tetrahedron 2012, 68, 8147-8155. [CrossRef]

42. Garcia-Amóros, J.; Reig, M.; Castro, M.C.R.; Cuadrado, A.; Raposo, M.M.M.; Velasco, D. Molecular photo-oscillators based on highly accelerated heterocyclic azo dyes in nematic liquid crystals. Chem. Commun. 2014, 50, 6704-6706. [CrossRef]

43. Castro, M.C.R.; Belsley, M.; Raposo, M.M.M. Synthesis and characterization of push-pull bithienylpyrrole NLOphores with enhanced hyperpolarizabilities. Dyes Pigments 2016, 131, 333-339. [CrossRef]

44. Castro, M.C.R.; Belsley, M.; Raposo, M.M.M. Push-pull second harmonic generation chromophores bearing pyrrole and thiazole heterocycles functionalized with several acceptor moieties: Syntheses and characterization. Dyes Pigments 2016, 128, 89-95. [CrossRef]

45. Fernandes, S.S.M.; Belsley, M.; Ciarrocchi, C.; Licchelli, M.; Raposo, M.M.M. Terpyridine derivatives functionalized with (hetero)aromatic groups and the corresponding Ru complexes: Synthesis and characterization as SHG chromophores. Dyes Pigments 2018, 150, 49-58. [CrossRef] 
46. Fernandes, S.S.M.; Castro, M.C.R.; Mesquita, I.; Andrade, L.; Mendes, A.; Raposo, M.M.M. Synthesis and characterization of novel thieno[3,2-b]thiophene based metal-free organic dyes with different heteroaromatic donor moieties as sensitizers for dye-sensitized solar cells. Dyes Pigments 2017, 136, 46-53. [CrossRef]

47. Fernandes, S.S.M.; Mesquita, I.; Andrade, L.; Mendes, A.; Justino, L.L.G.; Burrows, H.D.; Raposo, M.M.M. Synthesis and characterization of push-pull bithiophene and thieno[3,2-b]thiophene derivatives bearing an ethyne linker as sensitizers for dye-sensitized solar cells. Org. Electron. 2017, 49, 194-205. [CrossRef]

48. Fernandes, S.S.M.; Castro, M.C.R.; Pereira, A.I.; Mendes, A.; Serpa, C.; Pina, J.; Justino, L.L.G.; Burrows, H.D.; Raposo, M.M.M. Optical and photovoltaic properties of thieno[3,2-b]thiophene-based push-pull organic dyes with different anchoring groups for dye-sensitized solar cells. ACS Omega 2017, 2, 9268-9279. [CrossRef] [PubMed]

49. Fernandes, S.; Pereira, A.; Ivanou, D.; Mendes, A.; Raposo, M. Benzothiadiazole derivatives functionalized with two different (hetero)aromatic donor groups: Synthesis and evaluation as $\mathrm{TiO}_{2}$ sensitizers for DSSCs. Dyes Pigments 2018, 151, 89-94. [CrossRef]

50. Fernandes, S.S.M.; Belsley, M.; Pereira, A.; Ivanou, D.; Mendes, A.; Justino, L.L.G.; Burrows, H.D.; Raposo, M.M.M. Pushpull $\mathrm{N}, \mathrm{N}$-diphenylhydrazones bearing bithiophene or thienothiophene spacers as NLO second harmonic generators and as photosensitizers for nanocrystalline $\mathrm{TiO}_{2}$ DSSCs. ACS Omega 2018, 3, 12893-12904. [CrossRef]

51. Abbotto, A.; Beverina, L.; Manfredi, N.; Pagani, G.A.; Archetti, G.; Kuball, H.-G.; Wittenburg, C.; Heck, J.; Holtmann, J. Secondorder nonlinear optical activity of dipolar chromophores based on pyrrole-hydrazono donor moieties. Chem. Eur. J. 2009, 15, 6175-6185. [CrossRef] [PubMed]

52. Herbivo, C.; Comel, A.; Kirsch, G.; Fonseca, A.M.C.; Belsley, M.; Raposo, M.M.M. Synthesis and characterization of novel, thermally sTable 2-aryl-5-dicyanovinylthiophenes and 5-aryl-5'-dicyanovinyl-2,2'-bithiophenes as potentially promising nonlinear optical materials. Dyes Pigments 2010, 86, 217-226. [CrossRef]

53. Fernandes, S.S.M.; Herbivo, C.; Aires-de-Sousa, J.; Comel, A.; Belsley, M.; Raposo, M.M.M. Theoretical and experimental studies of aryl-bithiophene based push-pull $\pi$-conjugated heterocyclic systems bearing cyanoacetic or rhodanine-3-acetic acid acceptors for SHG nonlinear optical applications. Dyes Pigments 2018, 149, 566-573. [CrossRef]

54. Dalton, L.R.; Sullivan, P.A.; Bale, D.H. Electric field poled organic electro-optic materials: State of the art and future prospects Chem. Rev. 2010, 110, 25-55. [CrossRef]

55. Ohmori, Y. Development of organic light-emitting diodes for electro-optical integrated devices. Laser Photon. Rev. 2010, 4, 300-310. [CrossRef]

56. Allard, S.; Forster, M.; Souharce, B.; Thiem, H.; Scherf, U. Organic semiconductors for solution-processable field-effect transistors (OFETs). Angew. Chem. Int. Ed. 2008, 47, 4070-4098. [CrossRef] [PubMed]

57. Qian, G.; Wang, Z.Y. Near-infrared organic compounds and emerging applications. Chem. Asian J. 2010, 5, 1006-1029. [CrossRef]

58. Cinar, M.E.; Ozturk, T. Thienothiophenes, dithienothiophenes, and thienoacenes: Syntheses, oligomers, polymers, and properties. Chem. Rev. 2015, 115, 3036-3140. [CrossRef] [PubMed]

59. Lee, M.-W.; Kim, J.-Y.; Lee, D.-H.; Ko, M.J. Novel D- $\pi$-A organic dyes with thieno[3,2- $b$ ]thiophene-3,4-ethylenedioxythiophene unit as a $\pi$-bridge for highly efficient dye-sensitized solar cells with long-term stability. ACS Appl. Mater. Interfaces 2014, 6 , 4102-4108. [CrossRef]

60. Liu, H.; Wu, F.; Zhao, B.; Meng, L.; Wang, G.; Zhang, J.; Shen, P.; Tan, S. Synthesis and photovoltaic properties of the acceptor pended push-pull conjugated polymers incorporating thieno[3,2-b] thiophene in the backbone chain or side chains. Dyes Pigments 2015, 120, 44-51. [CrossRef]

61. Kakiage, K.; Aoyama, Y.; Yano, T.; Otsuka, T.; Kyomen, T.; Unno, M.; Hanaya, M. An achievement of over 12 percent efficiency in an organic dye-sensitized solar cell. Chem. Commun. 2014, 50, 6379-6381. [CrossRef] [PubMed]

62. Kakiage, K.; Aoyama, Y.; Yano, T.; Oya, K.; Fujisawa, J.-I.; Hanaya, M. Highly-efficient dye-sensitized solar cells with collaborative sensitization by silyl-anchor and carboxy-anchor dyes. Chem. Commun. 2015, 51, 15894-15897. [CrossRef]

63. Yen, Y.-S.; Hsu, Y.-C.; Lin, J.T.; Chang, C.-W.; Hsu, C.-P.; Yin, D.-J. Pyrrole-based organic dyes for dye-sensitized solar cells. J. Phys. Chem. C 2008, 112, 12557-12567. [CrossRef]

64. Li, Q.; Lu, L.; Zhong, C.; Huang, J.; Huang, Q.; Shi, J.; Jin, X.; Peng, T.; Qin, J.; Li, Z. New pyrrole-based organic dyes for dye-sensitized solar cells: Convenient synthesis and high efficiency. Chem. Eur. J. 2009, 15, 9664-9668. [CrossRef] [PubMed]

65. Li, Q.; Lu, L.; Zhong, C.; Shi, J.; Huang, Q.; Jin, X.; Peng, T.; Qin, J.; Li, Z. New indole-based metal-free organic dyes for dye-sensitized solar cells. J. Phys. Chem. B 2009, 113, 14588-14595. [CrossRef]

66. Mikroyannidis, J.A.; Roy, M.S.; Sharma, G.D. Synthesis of new low band gap dyes with $\mathrm{BF}_{2}$-azopyrrole complex and their use for dye-sensitized solar cells. J. Power Sources 2010, 195, 5391-5398. [CrossRef]

67. Li, Q.; Shi, J.; Li, H.; Li, S.; Zhong, C.; Guo, F.; Peng, M.; Hua, J.; Qin, J.; Li, Z. Novel pyrrole-based dyes for dye-sensitized solar cells: From rod-shape to "H" type. J. Mater. Chem. 2012, 22, 6689-6696. [CrossRef]

68. Li, H.; Yang, L.; Tang, R.; Hou, Y.; Yang, Y.; Wang, H.; Han, H.; Qin, J.; Li, Q.; Li, Z. Organic dyes incorporating N-functionalized pyrrole as conjugated bridge for dye-sensitized solar cells: Convenient synthesis, additional withdrawing group on the $\pi$-bridge and the suppressed aggregation. Dyes Pigments 2013, 99, 863-870. [CrossRef]

69. Kim, B.H.; Freeman, H.S. New $N$-methyl pyrrole and thiophene based D- $\pi-A$ systems for dye-sensitized solar cells. Dyes Pigments 2013, 96, 313-318. [CrossRef] 
70. Tejada, R.P.; Pelleja, L.; Palomares, E.; Franco, S.; Orduna, J.; Garin, J.; Andreu, R. Novel 4H-pyranylidene organic dyes for dye-sensitized solar cells: Effect of different heteroaromatic rings on the photovoltaic properties. Org. Electron. 2014, 15, 3237-3250. [CrossRef]

71. Manfredi, N.; Cecconi, B.; Abbotto, A. Multi-branched multi-anchoring metal-free dyes for dye-sensitized solar cells. Eur. J. Org. Chem. 2014, 2014, 7069-7086. [CrossRef]

72. Raposo, M.M.M.; Herbivo, C.; Hugues, V.; Clermont, G.; Castro, M.C.R.; Comel, A.; Blanchard-Desce, M. Synthesis, fluorescence, and two-photon absorption properties of push-pull 5-arylthieno[3,2-b]thiophene derivatives. Eur. J. Org. Chem. 2016, 31, 5263-5273. [CrossRef]

73. Cardona, C.M.; Li, W.; Kaifer, A.E.; Stockdale, D.; Bazan, G.C. Electrochemical considerations for determining absolute frontier orbital energy levels of conjugated polymers for solar cell applications. Adv. Mater. 2011, 23, 2367-2371. [CrossRef]

74. Hallensleben, M.L.; van Hooren, M.; Peters, M. Alternating copolymers based on 1-methylpyrrole and thiophene-Synthesis and electrochemical studies. Polymer Bull. 1998, 40, 167-172. [CrossRef]

75. Raposo, M.M.M.; Fonseca, A.M.C.; Castro, M.C.R.; Belsley, M.; Cardoso, M.F.S.; Carvalho, L.M.; Coelho, P.J. Synthesis and characterization of novel diazenes bearing pyrrole, thiophene and thiazole heterocycles as efficient photochromic and nonlinear optical (NLO) materials. Dyes Pigments 2011, 91, 62-73. [CrossRef]

76. Leonat, L.; Sbârcea, G.; Branzoi, I.V. Cyclic voltammetry for energy levels estimation of organic materials. UPB Sci. Bull. Ser. B Chem. Mater. Sci. 2013, 75, 111-118.

77. Khalid, M.; Hussain, R.; Hussain, A.; Ali, B.; Jaleel, F.; Imran, M.; Assiri, M.A.; Khan, M.U.; Ahmed, S.; Abid, S.; et al. Electron donor and acceptor influence on the nonlinear optical response of diacetylene-functionalized organic materials (DFOMs): Density functional theory calculations. Molecules 2019, 24, 2096. [CrossRef] [PubMed]

78. Hagfeldt, A.; Grätzel, M. Light-induced redox reactions in nanocrystalline systems. Chem. Rev. 1995, 95, 49-68. [CrossRef] 